\title{
Yarrowia lipolytica: a beneficious yeast in biotechnology as a rare opportunistic fungal pathogen: a minireview
}

\author{
Bartłomiej Zieniuk $^{1}$ (D) Agata Fabiszewska ${ }^{1}$
}

Received: 16 September 2018 / Accepted: 17 December 2018 / Published online: 21 December 2018

(c) The Author(s) 2018

\begin{abstract}
Yarrowia lipolytica is one of the most studied "non-conventional" yeast species capable of synthesizing a wide group of valuable metabolites, in particular lipases and other hydrolytic enzymes, microbial oil, citric acid, erythritol and $\gamma$-decalactone. Processes based on the yeast have GRAS status ("generally recognized as safe") given by Food and Drug Administration. The majority of research communications regarding to Y. lipolytica claim that the yeast species is non-pathogenic. In spite of that, Y. lipolytica, like other fungal species, can cause infections in immunocompromised and critically ill patients. The yeast possess features that facilitate invasion of the host cell (particularly production of hydrolytic enzymes), as well as the protection of the own cells, such as biofilm formation. The aim of this study was to present well-known yeast species $Y$. lipolytica as a rare opportunistic fungal pathogen. Possible pathogenicity and epidemiology of this yeast species were discussed. Antifungal drugs susceptibility and increasing resistance to azoles in Y. lipolytica yeasts were also presented.
\end{abstract}

Keywords Drug susceptibility $\cdot$ Fungemia $\cdot$ Opportunistic pathogen $\cdot$ Virulence factors $\cdot$ Yarrowia lipolytica

\section{Introduction}

One of the latest World Health Organization (WHO) report shows a growing threat from antibiotic-resistant microorganisms (WHO report 2017). On the other hand fungal diseases are not less hazardous. The incidence of fungal diseases especially in critically ill patients is thought to be increasing most commonly involving Candida and Aspergillus species (Beed et al. 2014; Brown et al. 2012). Due to an increase of population of immunocompromised patients and use of antifungal drugs in prophylaxis there have been appeared, other than mentioned above, species of yeasts and molds which can cause severe health problems (Nucci and Marr 2005). The aim of this study was to present well-known yeast species Yarrowia lipolytica as a poorly known opportunistic fungal pathogen. Although Y. lipolytica has a long history

Electronic supplementary material The online version of this article (https://doi.org/10.1007/s11274-018-2583-8) contains supplementary material, which is available to authorized users.

Bartłomiej Zieniuk

bartlomiej_zieniuk@sggw.pl

1 Department of Chemistry, Faculty of Food Sciences, Warsaw University of Life Sciences, 159 c Nowoursynowska St., 02-776 Warsaw, Poland of usage in food industry and an expanding biotechnological potential, the yeast species could be an example of a rare opportunistic fungal pathogen, which cause infections in premature newborns, immunocompromised and critically ill patients (Zhao et al. 2015). Although the first attempt to discuss safety of $Y$. lipolytica usage was made by Groenewald et al. (2014), this review lists possible virulence factors and drug susceptibility in the light of scientific announcements from the last few years, which has not been summarized yet. Moreover, there was exploited the issue by listing all known cases of illness connected with the presence of $Y$. lipolytica yeast what was evidenced in 110 patients.

\section{Yarrowia lipolytica - an overview}

Yarrowia lipolytica is a member of the Ascomycota phylum. The yeast species was formerly named as Candida, Endomycopsis or Saccharomycopsis lipolytica. The generic name "Yarrowia" refers to David Yarrow, researcher from Delft Microbiology Laboratory (Netherlands), who has identified this genus. The species name "lipolytica" is associated with the ability of hydrolyzing lipids (Nicaud 2012). The complete genome of the Y. lipolytica E150 strain (CLIB99) was published in 2004 by the Génolevures Consortium. The 
size of the yeast genome is not constant for all wild and laboratory strains and ranges from 12.7 to $22.1 \mathrm{Mb}$. The $Y$. lipolytica genome encodes 6448 genes and the number of chromosomes ranges from 4 to 6 (Dujon et al. 2004). Yeast $Y$. lipolytica belongs to heterothallic species with spores of various conjugation types. The frequency of conjugation in natural isolates is very low and wild strains are mostly haploids (Barth and Gaillardin 1997; Kurtzman et al. 2011).

Yarrowia lipolytica is widespread in nature. It is isolated from dairy products, such as Camembert and Rokpol cheeses (Roostita and Fleett 1996; Szczepaniak and Wojtatowicz 2011), dry fermented sausages (Flores et al. 2015) and other environments with high content of fats or hydrocarbons, for example rancid margarine, oil-polluted soil and sea water, as the yeast is able to utilize hydrophobic substrates such as hydrocarbons, fatty acids and lipids (Hassanshahian et al. 2012; Krzyczkowska and Fabiszewska 2015). Secretion of lipases by these microorganisms results in lipolysis of triacylglycerols, and proteases hydrolyze proteins. These processes may be desirable in many technological processes, e.g. in creating the characteristic taste and shortening the ripening time, but on the other hand, uncontrolled development of these microorganisms may pose a threat to food quality, e.g. causing an unfavorable appearance and texture (Carreira et al. 1998; Groenewald et al. 2014).

The yeast is used as a model for the study of dimorphism, degradation of hydrophobic substrates, lipid metabolism, protein secretion and peroxisome biogenesis (Beopoulos et al. 2009; Fickers et al. 2005). It is capable of synthesizing a wide group of valuable metabolites, for example lipases, proteases and other hydrolytic enzymes, microbial oil with high content of unsaturated fatty acids, citric acid, erythritol and $\boldsymbol{\gamma}$-decalactone (Krzyczkowska 2012; Fabiszewska et al. 2014; Papanikolaou and Aggelis 2011; Tomaszewska et al. 2014). Biotechnological processes based on the yeast species have GRAS ("generally recognized as safe") status given by Food and Drug Administration (FDA) (Rywińska et al. 2013).

Interestingly, in 2009, the Polish company Skotan SA in cooperation with the Wrocław University of Environmental and Life Sciences, started the production of $Y$. lipolytica biomass (SCP, single cell protein) from waste glycerol and obtained registration of the feed in the European Union. There are also provided the researches on probiotic properties of the species (Rywińska et al. 2013). Only Amano Enzymes uses $Y$. lipolytica lipase in an enzyme preparation under the trade name Amano N-AP. In the past, enzymes from $Y$. lipolytica were used by Fluka, but they ceased their use due to the high thermolability and proteolytic enzyme content in the extract (Brígida et al. 2014). Recently, yeast $Y$. lipolytica can be used for making yeast dough for the feeding of stimulating bee colonies (Apiyarr preparation, Łysoń company, Poland) and the yeast are present in Biopuls preparation for vegetative and generative growth of plants by Micro-life company (Poland) (Londzin et al. 2015; http:// www.biopuls.eu/index.php?page=original).

\section{Epidemiology and pathogenicity of Yarrowia lipolytica}

First $Y$. lipolytica (C. lipolytica) infection was reported in 1976 and it was ocular candidiasis (Nitzulescu and Niculescu 1976). Then in 1985 there was evidenced the first case of fungemia caused by $Y$. lipolytica. It was isolated from blood and intravenous catheter of a patient with recurrent fever (Wehrspann and Füllbrandt 1985). Moreover, Rajagopalan et al. (1996) have reported first occurrence of vaginal colonization by $Y$. lipolytica in asymptomatic 25-year-old woman. Furthermore, case report by Boyd et al. (2017) has shown that $Y$. lipolytica can cause cutaneous infection. 63-year-old immunocompetent woman had epidermal necrosis and minimal dermal inflammation due to yeast presence in her non-healing wound.

Infections due to $Y$. lipolytica have been increasingly described in persons which have been catheterizated for a long time (D'Antonio et al. 2002; Özdemir et al. 2011). Shin et al. (2000) have described a nosocomial outbreak of $Y$. lipolytica fungemia in pediatric patients with central venous catheters. Use of broad-spectrum antibiotics, immunological and hematological disorders, parenteral nutrition and prolonged hospitalization are the main factors affecting development of the infection (Trabelsi et al. 2015). Trabelsi et al. (2015) reported 55 cases of septicemia caused by $Y$. lipolytica occurred between October 2012 and June 2014 in the intensive care unit (ICU) in Tunisian hospital and after treatment $61.8 \%$ of patients have been cured. $Y$. lipolytica has been also isolated from nasopharynx, oropharynx, sputum and bronchial washing specimens, as well as from stool samples (Koivikko et al. 1988; Walsh et al. 1989).

Nevertheless, $Y$. lipolytica could be a part of an intestinal mycobiota, because it is isolated also from stool samples of healthy people (Gouba and Drancourt 2015). Irby et al. (2014) have suggested that $Y$. lipolytica should be considered as normal flora of adult respiratory tract. Between 2000 and 2010 Y. lipolytica was isolated from 24 patients, which 17 isolates originated from lung tissues.

Supplementary Table 1 summarizes 110 cases of Y. lipolytica clinical isolates. The data comes from 22 scientific reports that appeared between 1976 and 2017 (Agarwal et al. 2008; Belet et al. 2006; Blanco et al. 2009; Chang et al. 2001; D'Antonio et al. 2002; Garcia-Martos et al. 1993; Gouba and Drancourt 2015; Irby et al. 2014; Kang et al. 2008; Koivikko et al. 1988; Lai et al. 2012; Levy et al. 2003; Mazumder et al. 2015; Ninin et al. 1997; Nitzulescu and Niculescu 1976; Özdemir et al. 2011; Rajagopalan et al. 
1996; Shin et al. 2000; Trabelsi et al. 2015; Walsh et al. 1989; Wehrspann and Fullbrandt 1985; Ye et al. 2011; Zheng et al. 2009). The median age of the patients was 40 (patients were aged from 2 days old to 90 years old). Men accounted for $51.82 \%$ of cases $(n=57)$, woman $22.73 \%(n=25)$, and in other cases there was no information about gender. There were only $6 \%$ of known patients under 3 years old $(n=83)$ and $5 \%$ of children between 4 and 10 years old. $31 \%$ of patients were between 41 and 60 years old and only $18 \%$ were above 60 . Yeast isolates were recovered from blood $(68.18 \%, \mathrm{n}=75)$, lungs $(15.45 \%, \mathrm{n}=17)$, skin and wounds $(5.45 \%, n=6)$, eyes $(3.64 \%, n=3)$ and other clinical specimens such as: breast tissue, bronchoalveolar lavage fluid, duodenal mass, intraabdominal abscess, mesenteric mass, sinus aspirate, vagina and stool. When analysing the characteristics of patients in whom $Y$. lipolytica was isolated it can be noticed that usually there were no detected coinfections. In 15 of 29 described cases such coinfections were notified, most often by $C$. albicans $(\mathrm{n}=6)$. Few other Candida species $(\mathrm{n}=5)$, staphylococci $(\mathrm{n}=4)$, streptococci $(\mathrm{n}=2), E$. coli $(\mathrm{n}=2)$, M. tuberculosis $(\mathrm{n}=2)$ and some other individual species were isolated together with $Y$. lipolytica colonies. In 6 patients more than one species was identified along with Yarrowia. There was noticed more than 50 different diseases in people from whom tissues $Y$. lipolytica was isolated. In $24.04 \%$ patients $(n=104)$ factor/disease underlying their weakness and infections was polytraumatism, for 18 patients (17.31\%) it was surgery, for 16 patients (15.38\%) diabetes, for 7 patients $(7.69 \%)$ leukemia. If we look at fungal disease which were diagnosed in men from whom $Y$. lipolytica was isolated, the most usually identified disease entity was fungemia $(51 \%)$ or both: fungemia and catheter-related candidemia (20\%). Only one case of granuloma, cutaneous infection, vaginal colonization, ocular candidiasis and acute keratitis were described. Noteworthy, commonly the patients have catheter $(88 \%, \mathrm{n}=82)$, which was in majority of cases not removed $(90 \%, \mathrm{n}=60)$. This observations are in line with D'Antonio et al. (2002), Özdemir et al. (2011) and Trabelsi et al. (2015). Predominantly amphotericin B and fluconazole were used to cure the patents, which $42.73 \%(n=47)$ were cleared, and 32 (29.09\%) patients died.

\section{Virulence factors of $Y$. lipolytica}

Despite the fact that $Y$. lipolytica is regarded as weakly pathogenic organism, these yeasts present a number of features that allow an effective invasion of the host organism. Hydrolytic enzymes are one of the major factors, which could affect the pathogenicity of $Y$. lipolytica. This fungus is able to produce wide range of hydrolases, such as: proteases, phospholipases and hemolysins, which help in the invasion of tissues (Abbes et al. 2017; Kantarcioglu and Yucel
2002). Phospholipases and proteases secreted by yeasts play an important role in the damage of cell membranes, which consist of lipids and proteins. Moreover, proteases are capable of degrading epithelial and mucosal components, for example collagen and keratin (Fotedar and Al-Hedaithy 2005). Additionally, the most common human fungal pathogen C. albicans and other non-albicans Candida uses proteolytic enzymes to degradation of antibodies, complement and cytokines (Monod et al. 2002). Similar mechanism may occur in Y. lipolytica yeasts, but further studies are needed. $Y$. lipolytica as a former member of the Candida genus is compared to $C$. albicans - the most frequently isolated fungal pathogen in humans. Due to high pathogenicity of that yeast species, $C$. albicans is a good example to comparison, despite that these two species are quite evolutionarily distant (Barns et al. 1991).

Kantarcioglu and Yucel (2002) have examined 95 clinical Candida isolates and among these isolates four of them were $Y$. lipolytica yeasts. Three of four isolates showed protease activity and none of them showed phospholipase activity. In another research $58 \mathrm{Y}$. lipolytica isolates of blood, urine and vaginal origin were evaluated to produce hydrolytic enzymes in comparison with $C$. albicans and C. glabrata. $98.2 \%$ of $Y$. lipolytica isolates showed caseinase activity and only vaginal isolates showed phospholipase activity and the hemolytic activity between the three species showed no significant differences (Abbes et al. 2017).

Lipases are hydrolytic enzymes, which may also play its role during infections. Microbial lipases (EC 3.1.1.3) are widely used in food technology, organic chemistry and biotechnology. The lipolytic activity of $Y$. lipolytica for the first time was described by Peters and Nelson (1948), but genes encoding lipase proteins have been discovered since 2000s (Pignède et al. 2000). Lipases and esterases of the $Y$. lipolytica species are coded by the lipase gene family - LIP and the major extracellular lipase protein is Lip2p, which is encoded by LIP2 gene (Fickers et al. 2011). Putative roles of extracellular lipases were discussed by Stehr et al. (2003). The most important function of lipases secreted by microorganisms is lipid digestion and thanks to lipolysis the yeast could use hydrophobic carbon sources for growth. Utilization of unusual carbon sources by $Y$. lipolytica is frequently discussed topic by biotechnologists (Fickers et al. 2005). According to Stehr et al. (2003) free fatty acids and other products of lipolysis (mono- and diacylglycerols) could affect different immune cells, initiate the inflammatory process and support adhesion to host cells.

Holzschu et al. (1979) compared 11 yeasts species of industrial interest with $C$. albicans for their potential pathogenicity. Untreated and cortisone-treated mice were inoculated with yeasts, such as $Y$. lipolytica, $S$. cerevisiae and other Candida species. C. tropicalis caused infections similar to $C$. albicans. Other yeasts were not recovered 
after 6 days or recovered, but did not caused infections. In accordance to $Y$. lipolytica, authors suggested that maximum growth temperature of that yeasts is near $34{ }^{\circ} \mathrm{C}$, therefore the species was not lethal or invasive for mice. Walsh et al. (1989) checked the virulence of fungemia isolate of $Y$. lipolytica in murine model. Mice received different dilutions of yeasts via the lateral tail vein. All animals survived 14 days of experiment. Mouse which received the highest inoculum of $Y$. lipolytica had two abscesses in the left kidney and in the culture with kidney tissue that yeasts were present. Other tissues (brain, liver, spleen) were free of microbial contaminants and lesions. In comparison with $Y$. lipolytica, C. albicans caused mortality in all mice within the 2 week of experiment.

Adhesion to the host cells and hyphae formation can be also other significant virulence factors of the yeast species. $Y$. lipolytica is species of dimorphic yeast, which means that it grows as yeast-like cells or forms hyphae or pseudohyphae (Barth and Gaillardin 1997). Mechanism of dimorphic transition in Y. lipolytica is not well characterized, because filamentation of cells is a complex process. Over the years, scientists have published plenty of reports about factors and compounds affecting or inhibiting cells filamentation. It could be induced by carbon and nitrogen source, $\mathrm{pH}$ value, temperature, oxygenation and it's also dependent on strain specificity (Kerkhoven et al. 2016). CLA4 gene is reported to play role in dimorphism of $Y$. lipolytica. It encodes Cla4 protein kinase, which is highly homologous to Cla4 protein kinases of $C$. albicans and S. cerevisiae. Deletion of CLA4 gene is not lethal, however, due to lack of this gene mutants of $Y$. lipolytica cannot form mycelium (Szabo 2001). Other genes involved in yeast-to-hyphae transition are YlRACl and YlBMH1. First of them encoding a $\mathrm{G}$ protein of the Rho family and the second encoding a 14-3-3 protein. Transcription levels of these genes increased during the yeast-to-hyphae transition (Hurtado et al. 2000; Hurtado and Rachubinski 2002). Moreover, Morales-Vargas et al. (2012) have reported 61 up- and 165 downregulated genes involved in dimorphism, where some of these genes were homologous with S. cerevisiae.

Biofilm is a form of microbial community that is associated with a surface (Desai et al. 2014). Due to presence of extracellular matrix and complex structure, biofilms protect yeast cells against antifungal agents (Fanning and Mitchell 2012). D'Antonio et al. (2002) reported that Y. lipolytica produced large amount of slime in glucose-based medium and that confirms the ability of biofilm production and also adhesion to and colonization of plastic central venous catheter. Abbes et al. (2017) studied biofilm formation by $Y$. lipolytica in comparison with $C$. albicans and C. glabrata. Biofilms development have been examined in vitro (using 96-well polystyrene microtiter plates) as well as in vivo in a rat subcutaneous model. In contrast to Candida species, biofilms obtained by $Y$. lipolytica after catheter subcutaneous implementation seemed to be more compact hyphal layer and also number of cells was significantly greater.

\section{Drug susceptibility of Yarrowia lipolytica}

Antifungals are antimycotic drugs used to treat or prevent fungal diseases. These medications can be divided into the following classes: polyenes, azoles, echinocandins, and others. Polyenes, such as Amphotericin B and Nystatin bind to sterols in the cell membrane, mainly ergosterol, which causes disruption of the cell membrane integrity and resulting in leakage of ions and other cytoplasmic components and cell lysis (Odds et al. 2003). Azoles are the largest group of antifungal agents. The most common in clinical use are triazoles, such as Fluconazole and Itraconazole. Mechanism of their action is to inhibit 14a-demethylation of lanosterol in the ergosterol biosynthetic pathway (Ghannoum and Rice 1999). Echinocandins (Anidulafungin, Caspofungin and Micafungin) are inhibitors of glucan synthesis in the cell wall (Ghannoum and Rice 1999). Another used antifungal drug is Flucytosine, also known as 5-fluorocytosine. Flucytosine is converted inside fungal cell to 5-fluorouracil and other compounds, resulting in inhibition of DNA synthesis (Odds et al. 2003).

Antifungal susceptibility testing of the yeasts provides meaningful information for epidemiological, clinical and therapeutic issues. As mentioned before, $Y$. lipolytica was often isolated from patients with central venous catheters. In some cases, removal of central vein catheter in conjunction with an antifungal drug was the best way in treatment of catheter-related candidemia. On the other hand, sometimes catheter could not be removed due to patient's condition or type of catheter. Antifungal-lock technique (ALT) was proposed as an alternative method for treatment of catheter-related infections. ALT consists of filling the catheter lumen with antimicrobials and leaving them for an appropriate period of time (Mermel et al. 2001). Özdemir et al. (2011) reported first case of using ALT in combination with systemic therapy to treat $Y$. lipolytica fungemia. Intravenous caspofungin and caspofungin-lock therapy was initiated in 9-year-old patient with neuroblastoma. Solution of antifungal, dextrose and heparin was placed in the lines for $12 \mathrm{~h}$. Cultures were negative after 4 days of treatment, and therapy was stopped after 14 days and no relapse was seen then.

A panel of experts of the European Society of Clinical Microbiology and Infectious Diseases (ESCMID) and the European Confederation of Medical Mycology (ECMM) presented an overview of data on rare invasive yeast infections. $Y$. lipolytica was also mentioned in the report and authors claimed that clinical significance of that yeast species is uncertain and minimal inhibitory concentration 
(MIC) of fluconazole is higher than MIC obtained for $C$. albicans (Arendrup et al. 2014). MIC distribution of Yarrowia lipolytica isolates is presented in Table 1 . The data comes from seven scientific reports (Blanco et al. 2009; D'Antonio et al. 2002; Diekema et al. 2009; Lai et al. 2012; Shin et al. 2000; Walsh et al. 1989; Zhao et al. 2015). Additionally, $\mathrm{MIC}_{50}$ and $\mathrm{MIC}_{90}$ values were calculated, which represents MIC values at which $50 \%$ or $90 \%$ of isolates in population are inhibited, respectively. Both MIC, $\mathrm{MIC}_{50}$ and $\mathrm{MIC}_{90}$ are important parameters in describing the susceptibility of isolates to antimicrobials.

Zhao et al. (2015) compared susceptibility of 14 Y. lipolytica isolates to 9 different antifungal drugs. All 14 isolates showed low MICs to echinocandins and amphotericin B, 4 isolates had MICs of $<4 \mu \mathrm{g} / \mathrm{ml}$ to flucytosine and susceptibility to azoles was more diverse, where MIC values for fluconazole were highest. Diekema et al. (2009) examined the susceptibility of 658 clinical isolates of rare species of Candida yeasts (including 16 strains of Y. lipolytica) to amphotericin, fluconazole, posaconazole, voriconazole, anidulafungin, caspofungin and micafungin. Echinocandins and voriconazole exhibited highest activity against $Y$. lipolytica, and MICs of that antifungals were not higher than $2 \mu \mathrm{g} / \mathrm{ml}$, but most of the tested strains were not susceptible to amphotericin B and fluconazole.

Barchiesi et al. (1999) compared in vitro activity of five antifungals (fluconazole, itraconazole, ketoconazole, flucytosine and amphotericin B) against uncommon clinical isolates of Candida spp. Results showed that strains differ in susceptibility to antifungal agents. Among the tested strains authors identified a strain of $Y$. lipolytica, with low susceptible to fluconazole and also that strain was cross-resistant to ketoconazole and itraconazole. Sixty-seven percent of $Y$. lipolytica strains have been defined as isolates with reduced susceptibility to flucytosine, therefore that antifungal agent is rarely used in monotherapy of fungal infections.

The studies quoted above show that voriconazole, caspofungin, micafungin and anidulafungin may be better treatment options than fluconazole or 5-fluorocytosine. Results show also a phenomenon of increasing resistance to azoles. Mechanism of azole resistance occurring in Candida genus is associated with, among others, overexpression of $C D R 1$ (Candida drug resistance gene), CDR2 (a homologue of $C D R I$ ) and $M D R I$ (multidrug resistance gene) genes, which encode efflux pumps, that are capable of transporting antifungal drugs out of the cell. Another mechanism is occurring a point mutations in genes encoding enzymes, which should be targeted by antifungal drug. Mutations in ERG11 gene (encoding lanosterol $14 \alpha$-demethylase) prevent from biding azoles, resulting in a lack of inhibition of encoded enzyme, which is essential for ergosterol biosynthesis (major sterol found in cell membranes of fungi). Moreover, mutations can lead to overexpression of Erg11 protein, which

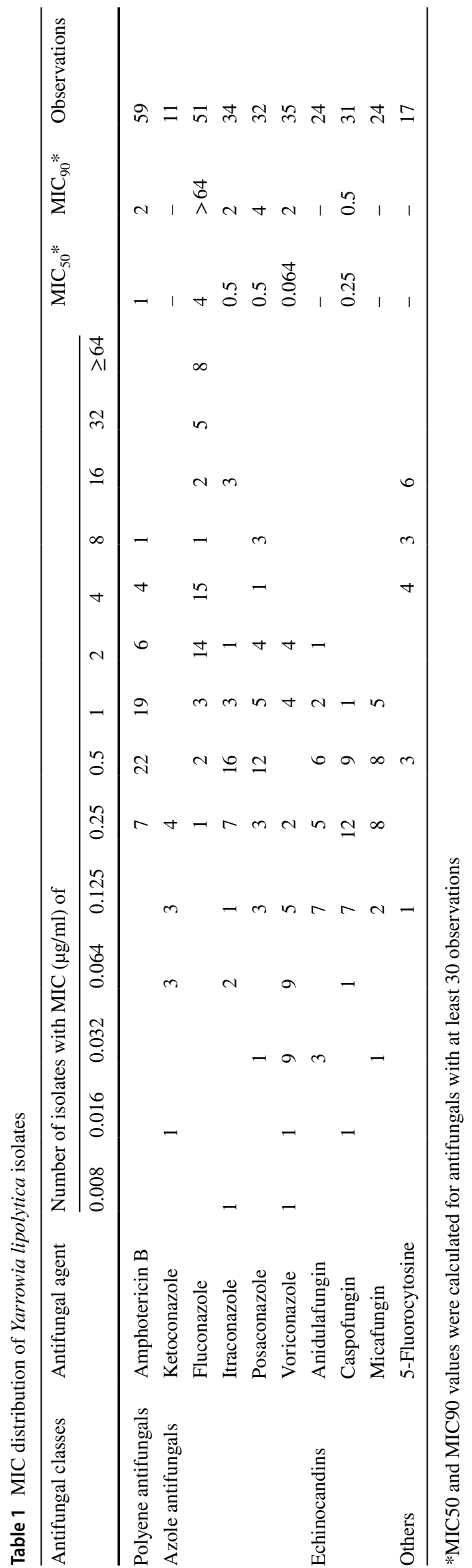


increase resistance to azoles (Gołąbek et al. 2015; Whaley et al. 2017). Additionally, mutations in ERG3 gene (encoding $\Delta^{5,6}$-desaturase) can lead to accumulation of $14 \mathrm{a}$-methylfecosterol in fungal membrane instead of ergosterol. As a result of reducing the amount of ergosterol in the membrane, resistance to azoles and polyenes increases (Kanafani and Perfect 2008). In the case of echinocandins resistance in $C$. albicans and other Candida spp., it results from point mutations in the FKS1 gene (involved in $\beta-1,3$-D-glucan synthesis). Substitution of amino acids in protein lead to elevating MIC value for echinocandins 5- to 100-fold (Cowen et al. 2015). Yeast can also be resistant to 5-fluorocytosine. This is due to the fact that mutations in cytosine deaminase and uracil phosphoribosyltransferase lead to defects in flucytosine metabolism what result in resistance to that antifungal drug (Ghannoum and Rice 1999). Mechanisms of resistance in $Y$. lipolytica have not been described yet, however, those listed above may also occur in this yeast species.

\section{Conclusion}

Yarrowia lipolytica is an yeast species phylogenetically distant from S. cerevisiae or other well-studied yeast species and known from its interesting physiological features. It is considered as a non-pathogenic microorganism and the U.S. Food and Drug Administration has given its metabolites the GRAS status. Moreover, the species is an inseparable element of the microflora accompanying many food products with a long history of occurrence in human diet. Nevertheless, in the light of the reviewed cases of yeast infections, $Y$. lipolytica may be also considered as a rare opportunistic fungal pathogen in patients with compromised immunity and those with catheters. Infections caused by this yeast species are very rare, however $Y$. lipolytica might be an epidemiological problem for critically ill patients in the future due to increasing resistance to antifungal drugs. The reported in the literature strains of $Y$. lipolytica differed in susceptibility to antifungal agents, mainly fluconazole and other azoles were investigated. In some cases mentioned in the review, infections were resolved without treatment, which may suggest low virulence of the species, therefore further studies are needed to compare the virulence of $Y$. lipolytica with other Candida spp. and to confirm its pathogenicity, as most of the yeast occurrences in patients were reported not earlier than 20 years ago. An interesting issue are virulence factors of $Y$. lipolytica, which have been proposed in the review. With a lot of certainty occurrence of Y. lipolytica infections yet do not cross with its usage in various industries as a microorganism with a huge biotechnological potential, but the pathogenicity of each foodborne microorganism should be monitored up to date.

\section{Compliance with Ethical Standards}

Conflict of interest The authors declare that they have no conflict of interest.

Ethical approval This article does not contain any studies with human participants or animals performed by any of the authors.

Open Access This article is distributed under the terms of the Creative Commons Attribution 4.0 International License (http://creativeco mmons.org/licenses/by/4.0/), which permits unrestricted use, distribution, and reproduction in any medium, provided you give appropriate credit to the original author(s) and the source, provide a link to the Creative Commons license, and indicate if changes were made.

\section{References}

Abbes S, Amouri I, Trabelsi H, Neji S, Sellami H, Rahmouni F, Makni F, Rebai T, Ayadi A (2017) Analysis of virulence factors and in vivo biofilm-forming capacity of Yarrowia lipolytica isolated from patients with fungemia. Med Mycol 55(2):193-202. https:// doi.org/10.1093/mmy/myw028

Agarwal S, Thakur K, Kanga A, Singh G, Gupta P (2008) Catheterrelated candidemia caused by Candida lipolytica in a child with tubercular meningitis. Indian J Pathol Microbiol 51:298-300. https://doi.org/10.4103/0377-4929.41709

Arendrup MC, Boekhout T, Akova M, Meis JF, Cornely OA, Lortholary $\mathrm{O}$, on behalf of the ESCMID EFISG study group and ECMM (2014) ESCMID and ECMM joint clinical guidelines for the diagnosis and management of rare invasive yeast infections. Clin Microbiol Infect 20(Suppl. 3):76-98. https://doi. org/10.1111/1469-0691.12360

Barchiesi F, Tortorano AM, Di Francesco LF, Cogliati M, Scalise G, Viviani MA (1999) In vitro activity of five antifungal agents against uncommon clinical isolates of Candida spp. J Antimicrob Chemother 43(2):295-299. https://doi.org/10.1093/jac/43.2.295

Barns SM, Lane DJ, Sogin ML, Bibeau C, Weisburg WG (1991) Evolutionary relationships among pathogenic Candida Species and Relatives. J Bacteriol 173(7):2250-2255. https://doi.org/10.1128/ jb.173.7.2250-2255.1991

Barth G, Gaillardin C (1997) Physiology and genetics of the dimorphic fungus Yarrowia lipolytica. FEMS Microbiol Rev 19(4):219-237. https://doi.org/10.1111/j.1574-6976.1997.tb00299.x

Beed M, Sherman R, Holden S (2014) Fungal infections and critically ill adults. Contin Educ Anaesth Crit Care Pain 14(6):262-267. https://doi.org/10.1093/bjaceaccp/mkt067

Belet N, Ciftçi E, Ince E, Dalgiç N, Oncel S, Güriz H, Yagmurlu A, Dindar H, Doğru U (2006) Caspofungin treatment in two infants with persistent fungemia due to Candida lipolytica. Scand J Infect Dis 38(6-7):559-562. https://doi.org/10.1080/003655405004040 52

Beopoulos A, Chardot T, Nicaud JM (2009) Yarrowia lipolytica: A model and a tool to understand the mechanisms implicated in lipid accumulation. Biochimie 91(6):692-6. https://doi.org/10.1016/j. biochi.2009.02.004

Biopuls Original Preparation by Microlife sp. z o.o. http://www.biopu ls.eu/index.php?page $=$ original. Accessed 15 Sept 2018

Blanco MT, Garcia-Martos P, Garcia-Tapia A, Fernandez C, Navarro J, Guerrero F (2009) Fungemia por Candida lipolytica: a proposito de 2 casos. Rev Iberoam Micol 26(3):211-212. https://doi. org/10.1016/j.riam.2009.02.004 (Article in Spanish) 
Boyd AS, Wheless L, Brady BG, Ellis D (2017) Cutaneous Yarrowia lipolytica infection in an immunocompetent woman. JAAD Case Rep 14(3):219-221. https://doi.org/10.1016/j.jdcr.2017.02.010

Brígida AIS, Amaral PFF, Coelho MAZ, GonÒ«alves LRB (2014) Lipase from Yarrowia lipolytica: production, characterization and application as an industrial biocatalyst. J Mol Catal B 101:148158. https://doi.org/10.1016/j.molcatb.2013.11.016

Brown GD, Denning DW, Gow NAR, Levitz SM, Netea MG, White TC (2012) Hidden killers: human fungal infections. Sci Transl Med 4(165):165rv13. https://doi.org/10.1126/scitranslmed.3004404

Carreira A, Paloma L, Loureiro V (1998) Pigment producing yeasts involved in the brown surface discoloration of ewes' cheese. Int J Food Microbiol 41:223-230. https://doi.org/10.1016/S0168 $-1605(98) 00054-3$

Chang CL, Park TH, Lee EY, Lim YK, Son HC (2001) Recurrent selflimited fungemia caused by Yarrowia lipolytica in a patient with acute myelogenous leukemia. J Clin Microbiol 39(3):1200-1201. https://doi.org/10.1128/JCM.39.3.1200-1201.2001

Cowen LE, Sanglard D, Howard SJ, Rogers PD, Perlin DS (2015) Mechanisms of antifungal drug resistance. Cold Spring Harb Perspect Med 5(7):a019752. https://doi.org/10.1101/cshperspec t.a019752

D’Antonio D, Romano F, Pontieri E, Fiortoni G, Caracciolo C, Bianchini S, Olioso P, Staniscia T, Sferra R, Boccia S, Vetuschi A, Federico G, Gaudio E, Carruba G (2002) Catheter-related candidemia caused by candida lipolytica in a patient receiving allogeneic bone marrow transplantation. J Clin Microbiol 40(4):13811386. https://doi.org/10.1128/JCM.40.4.1381-1386.2002

Desai JV, Mitchell AP, Andes DR (2014) Fungal biofilms, drug resistance, and recurrent infection. Cold Spring Harb Perspect Med 4(10):a019729. https://doi.org/10.1101/cshperspect.a019729

Diekema DJ, Messer SA, Boyken LB, Hollis RJ, Kroeger J, Tendolkar S, Pfaller MA (2009) In vitro activity of seven systemically active antifungal agents against a large global collection of rare candida species as determined by CLSI broth microdilution methods. J Clin Microbiol 47(10):3170-3177. https://doi.org/10.1128/ JCM.00942-09

Dujon B, Sherman D, Fischer G, Durrens P, Casaregola S, Lafontaine I, De Montigny J, Marck C, Neuveglise C, Talla E, Goffard N, Frangeul L, Aigle M, Anthouard V, Babour A, Barbe V, Barnay S, Blanchin S, Beckerich JM, Beyne E, Bleykasten C, Boisrame A, Boyer J, Cattolico L, Confanioleri F, Daruvar A, de Despons L, Fabre E, Fairhead C, Ferry-Dumazet H, Groppi A, Hantraye F, Hennequin C, Jauniaux N, Joyet P, Kachouri R, Kerrest A, Koszul R, Lemaire M, Lesur I, Ma L, Muller H, Nicaud J-M, Nikolski M, Oztas S, Ozier-Kalogeropoulos O, Pellenz S, Potier S, Richard GF, Straub ML, Suleau A, Swennen D, Tekaia F, WesolowskiLouvel M, Westhof E, Wirth B, Zeniou-Meyer M, Zivanovic I, Bolotin-Fukuhara M, Thierry A, Bouchier C, Caudron B, Scarpelli C, Gaillardin C, Weissenbach J, Wincker P, Souciet JL (2004) Genome evolution in yeasts. Nature 430:35-44. https:// doi.org/10.1038/nature02579

Fabiszewska AU, Stolarzewicz IA, Zamojska WM, BiałeckaFlorjańczyk E (2014) Carbon source impact on Yarrowia lipolytica KKP 379 lipase production. Appl Biochem Micro 50(4):404410. https://doi.org/10.1134/S000368381404005X

Fanning S, Mitchell AP (2012) Fungal biofilms. PLoS Pathog 8(4):e1002585. https://doi.org/10.1371/journal.ppat.1002585

Fickers P, Benetti PH, Waché Y, Marty A, Mauersberger S, Smit MS, Nicaud JM (2005) Hydrophobic substrate utilisation by the yeast Yarrowia lipolytica, and its potential applications. FEMS Yeast Res 5(6-7):527-543. https://doi.org/10.1016/j.femsy r.2004.09.004

Fickers P, Marty A, Nicaud JM (2011) The lipases from Yarrowia lipolytica: genetics, production, regulation, biochemical characterization and biotechnological applications. Biotechnol Adv 29(6):632-644. https://doi.org/10.1016/j.biotechadv .2011 .04 .005

Flores M, Corral S, Cano-García L, Salvador A, Belloch C (2015) Yeast strains as potential aroma enhancers in dry fermented sausages. Int J Food Microbiol 212:16-24. https://doi.org/10.1016/j. ijfoodmicro.2015.02.028

Fotedar R, Al-Hedaithy SS (2005) Comparison of phospholipase and proteinase activity in Candida albicans and $C$. dubliniensis. Mycoses 48(1):62-67. https://doi.org/10.111 1/j.1439-0507.2004.01057.x

García-Martos P, de la Rubia F, Palomo MJ, Alvarez MM, Marin P, Mira J (1993) Candida lipolytica, a new opportunistic pathogen. Enferm Infecc Microbiol Clin 11(3):163 (Article in Spanish)

Ghannoum MA, Rice LB (1999) Antifungal agents: mode of action, mechanisms of resistance, and correlation of these mechanisms with bacterial resistance. Clin Microbiol Rev 12(4):501-517

Gołąbek K, Strzelczyk JA, Owczarek A, Cuber P, Ślemp-Migiel A, Wiczkowski A (2015) Selected mechanisms of molecular resistance of Candida albicans to azole drugs. Acta Biochim Pol 62(2):247-251. https://doi.org/10.18388/abp.2014_940

Gouba N, Drancourt M (2015) Digestive tract mycobiota: a source of infection. Med Mal Infect 45(1-2):9-16. https://doi. org/10.1016/j.medmal.2015.01.007

Groenewald M, Boekhout T, Neuveglise C, Gaillardin C, van Dijck PWM, Wyss M (2014) Yarrowia lipolytica: safety assessment of an oleaginous yeast with a great industrial potential. Crit Rev Microbiol 40(3):187-206. https://doi.org/10.3109/10408 41X.2013.770386

Hassanshahian M, Tebyanian H, Cappello S (2012) Isolation and characterization of two crude oil-degrading yeast strains, Yarrowia lipolytica PG-20 and PG-32, from the Persian Gulf. Mar Pollut Bull 64(7):1386-1391. https://doi.org/10.1016/j.marpo lbul.2012.04.020

Holzschu DL, Chandler FW, Ajello L, Ahearn DG (1979) Evaluation of industrial yeasts for pathogenicity. Sabouraudia 17(1):71-78

Hurtado CA, Rachubinski RA (2002) Y1BMH1 encodes a 14-3-3 protein that promotes filamentous growth in the dimorphic yeast Yarrowia lipolytica. Microbiology 148:3725-3735. https://doi. org/10.1099/00221287-148-11-3725

Hurtado CA, Beckerich JM, Gaillardin C, Rachubinski RA (2000) A rac homolog is required for induction of hyphal growth in the dimorphic yeast Yarrowia lipolytica. J Bacteriol 182(9):23762386. https://doi.org/10.1128/JB.182.9.2376-2386.2000

Irby RF, Kandula M, Zadikany R, Sandin RL, Greene JN (2014) Yarrowia lipolytica as normal human flora: a case series of 24 patients with positive cultures and no attributable disease. Infect Dis Clin Pract 22(4):207-209. https://doi.org/10.1097/ IPC.0000000000000106

Kanafani ZA, Perfect JR (2008) Resistance to antifungal agents: mechanisms and clinical impact. Clin Infect Dis 46(1):120-128. https://doi.org/10.1086/524071

Kang KW, Yoon HJ, Jung SH, Cho SH, Kim HY, Yoo YW (2008) A case of Yarrowia lipolytica fungemia after raw beef ingestion. Korean J Med 74(5):566-569 (Article in Korean)

Kantarcioglu AS, Yücel A (2002) Phospholipase and protease activities in clinical Candida isolates with reference to the sources of strains. Mycoses 45(5-6):160-165. https://doi.org/10.104 6/j.1439-0507.2002.00727.x

Kerkhoven EJ, Pomraning KR, Baker SE, Nielsen J (2016) Regulation of amino-acid metabolism controls flux to lipid accumulation in Yarrowia lipolytica. NPJ Syst Biol Appl 2:16005. https ://doi.org/10.1038/npjsba.2016.5

Koivikko A, Kalimo K, Nieminen E, Viander M (1988) Relationship of immediate and delayed hypersensitivity to nasopharyngeal and intestinal growth of Candida 
albicans in allergic subjects. Allergy 43(3):201-205. https:// doi.org/10.1111/j.1398-9995.1988.tb00419.x

Krzyczkowska J (2012) The use of castor oil in the production of $\gamma$-decalactone by Yarrowia lipolytica KKP 379. Chem Technol 3(61):58-61. https://doi.org/10.5755/j01.ct.61.3.2717

Krzyczkowska J, Fabiszewska AU (2015) Yarrowia lipolytica Niekonwencjonalne drożdże w biotechnologii. Post Mikrobiol 54(1):33-43 (Article in Polish)

Kurtzman CP, Fell JW, Boekhout T (ed.) (2011) The yeasts: a taxonomic study, 5th ed. Elsevier, Amsterdam

Lai CC, Lee MR, Hsiao CH, Tan CK, Lin SH, Liao CH, Huang YT, Hsueh PR (2012) Infections caused by Candida lipolytica. J Infection 65(4):372-374. https://doi.org/10.1016/j.jinf.2012.06.011

Levy JM, Levin RS, Clancy JT (2003) Lower-extremity wounds inflicted by rats. J Am Podiat Med Assn 93(1):58-61. https://doi. org/10.7547/87507315-93-1-58

Londzin W, Buczek K, Zon M (2015) Zastosowanie drożdży Yarrowia lipolytica jako immunostymulującej paszy białkowej dla pszczół. Pasieka 4:30-34 (Article in Polish)

Mazumder SA, Todd WA, Cleveland KO (2015) Fatal Yarrowia lipolytica intra-abdominal abscess with persistent fungemia in a liver transplant recipient. Infect Dis Clin Pract 23:273-275. https://doi. org/10.1097/IPC.0000000000000251

Mermel LA, Farr BM, Sherertz RJ, Raad II, O'Grady N, Harris JS, Craven DE (2001) Guidelines for the management of intravascular catheter-related infections. Clin Infect Dis 32:1249-1272. https:// doi.org/10.1086/320001

Monod M, Capoccia S, Léchenne B, Zaugg C, Holdom M, Jousson O (2002) Secreted proteases from pathogenic fungi. Int J Med Microbiol 292(5-6):405-419. https://doi.org/10.1078/1438-4221-00223

Morales-Vargas AT, Domínguez A, Ruiz-Herrera J (2012) Identification of dimorphism-involved genes of Yarrowia lipolytica by means of microarray analysis. Res Microbiol 163(5):378-387. https://doi.org/10.1016/j.resmic.2012.03.002

Nicaud JM (2012) Yarrowia lipolytica. Yeast 29:409-418. https://doi. org/10.1002/yea.2921

Ninin E, Morin O, Tortorec LE, Milpied N, Moreau P, Harousseau JL (1997) Infection invasive à Candida lipolytica après allogreffe de moelle osseuse. J Mycol Med 7:212-214 (Article in French)

Nitzulescu V, Niculescu M (1976) Three cases of ocular candidiasis caused by Candida lipolytica. Arch Roum Pathol Exp Microbiol 35(3):269-272

Nucci M, Marr KA (2005) Emerging fungal diseases. Clin Infect Dis 41(4):521-526. https://doi.org/10.1086/432060

Odds FC, Brown AJP, Gow NAR (2003) Antifungal agents: mechanisms of action. TRENDS Microbiol 11(6):272-279. https://doi. org/10.1016/S0966-842X(03)00117-3

Özdemir H, Karbuz A, Çiftçi E, Dinçaslan HU, İnce E, Aysev D, Yavuz G, Doğru Ü (2011) Successful treatment of central venous catheter infection due to Candida lipolytica by caspofunginlock therapy. Mycoses 54(5):647-649. https://doi.org/10.111 1/j.1439-0507.2010.01964.x

Papanikolaou S, Aggelis G (2011) Lipids of oleaginous yeasts. Part I: Biochemistry of single cell oil production. Eur J Lipid Sci Technol 113:1031-1051. https://doi.org/10.1002/ejlt.201100014

Peters II, Nelson FE (1948) Preliminary characterization of the lipase of mycotorula lipolytica. J Bacteriol 55(5):593-600

Pignède G, Wang H, Fudalej F, Gaillardin C, Seman M, Nicaud JM (2000) Characterization of an extracellular lipase encoded by LIP2 in Yarrowia lipolytica. J Bacteriol 182(10):2802-2810. https ://doi.org/10.1128/JB.182.10.2802-2810.2000

Rajagopalan B, Mathews MS, Jacob M (1996) Vaginal colonisation by Candida lipolytica. Genitourin Med 72(2):146-147
Roostita R, Fleett GH (1996) The occurrence and growth of yeasts in Camembert and blue-veined cheeses. Int J Food Microbiol 28(3):393-404. https://doi.org/10.1016/0168-1605(95)00018-6

Rywińska A, Juszczyk P, Wojtatowicz M, Robak M, Lazar Z, Tomaszewska L, Rymowicz W (2013) Glycerol as a promising substrate for Yarrowia lipolytica biotechnological applications. Biomass Bioenerg 48:148-166. https://doi.org/10.1016/j.biombioe.2012.11.021

Shin JH, Kook H, Shin DH, Hwang TJ, Kim M, Suh SP, Ryang DW (2000) Nosocomial cluster of Candida lipolytica fungemia in pediatric patients. Eur J Clin Microbiol Infect Dis 19(5):344-349. https://doi.org/10.1007/s100960050491

Stehr F. Kretschmar M, Kröger C, Hube B, Schäfer W (2003) Microbial lipases as virulence factors. J Mol Catal B Enzym 22(5-6):347355. https://doi.org/10.1016/S1381-1177(03)00049-3

Szabo R (2001) Cla4 protein kinase is essential for filament formation and invasive growth of Yarrowia lipolytica. Mol Genet Genomics 265(1):172-179. https://doi.org/10.1007/s004380000405

Szczepaniak G, Wojtatowicz M (2011) Dobór szczepów Yarrowia lipolytica i Debaryomyces hansenii do szczepionki wspomagającej proces dojrzewania sera. Żywność Nauka Technologia Jakość 6(79):192-203 (Article in Polish)

Tomaszewska L, Rakicka M, Rymowicz W, Rywińska A (2014) A comparative study on glycerol metabolism to erythritol and citric acid in Yarrowia lipolytica yeast cells. FEMS Yeast Res 14(6):966-976. https://doi.org/10.1111/1567-1364.12184

Trabelsi H, Chtara K, Khemakhem N, Néji S, Cheikhrouhou F, Sellami H, Guidara R, Makni F, Bouaziz M, Ayadi A (2015) Fungemia caused by Yarrowia lipolytica. Mycopathologia 179(5-6):437445. https://doi.org/10.1007/s11046-015-9859-4

Walsh TJ, Salkin IF, Dixon DM, Hurd NJ (1989) Clinical, microbiological, and experimental animal studies of Candida lipolytica. $\mathrm{J}$ Clin Microbiol 27(5):927-931

Wehrspann P, Fullbrandt U (1985) Report of a case of Yarrowia lipolytica (Wickerham et al.) van der Walt and von Arx isolated from a blood culture. Mykosen 28(5):217-222

Whaley SG, Berkow EL, Rybak JM, Nishimoto AT, Barker KS, Rogers PD (2017) Azole antifungal resistance in Candida albicans and emerging non-albicans Candida species. Front Microbiol 7:2173. https://doi.org/10.3389/fmicb.2016.02173

WHO (2017) Prioritization of pathogens to guide discovery, research and development of new antibiotics for drug-resistant bacterial infections, including tuberculosis (WHO/EMP/IAU/2017.12). World Health Organization, Geneva

Ye Q, Xu X, Li J, Cao H (2011) Fungemia caused by Yarrowia lipolytica in a patient with acute lymphoblastic leukemia. J Pediatr Hematol Oncol 33:e120-e121. https://doi.org/10.1097/ MPH.0b013e3181f53dbb

Zhao Y, Chan JF, Tsang CC, Wang H, Guo D, Pan Y, Xiao Y, Yue N, Chen JH, Lau SK, Xu Y, Woo PC (2015) Clinical characteristics, laboratory identification, and in vitro antifungal susceptibility of Yarrowia (Candida) lipolytica isolates causing Fungemia: a multicenter, prospective surveillance study. J Clin Microbiol 53(11):3639-3645. https://doi.org/10.1128/JCM.01985-15

Zheng YC, Zeng JS, Li JW, Wang DJ, Wu YQ, Wu Y (2009) Granuloma caused by Candida lipolytica in China: first case report. J Clin Dermatol 38(1):9-11

Publisher's Note Springer Nature remains neutral with regard to jurisdictional claims in published maps and institutional affiliations. 